\title{
Fictive-friendship and the Fourth Gospel
}

\begin{abstract}
Author:
Zeba A. Crook ${ }^{1,2}$

Affiliations:

${ }^{1}$ Department of Religion and Classics, Carleton University, Canada

${ }^{2}$ Department of New Testament Studies, University of Pretoria, South Africa

Note:

Prof. Dr Zeba A. Crook Associate-Professor at Carleton University, Ontario, Canada, is participating in the research project of Prof. Dr Ernest van Eck in the Department of New Testament Studies of the Faculty of Theology at the University of Pretoria, South Africa. This article was initially presented as a paper at the International Meeting of the Context Group that was held on 02-05 August 2010 at the University of Pretoria, South Africa.
\end{abstract}

\section{Correspondence to:} Zeba Crook

Email:

zeba.crook@gmail.com

\section{Postal address:}

2a43 Paterson Hall, Carleton University, 1125 Colonel By Drive, Ottawa, ON, K1S 5B6, Canada

\section{Dates:}

Received: 11 Oct. 2010

Accepted: 21 Nov. 2010

Published: 03 Oct. 2011

How to cite this article: Crook, Z.A., 2011, 'Fictivefriendship and the Fourth Gospel', HTS Teologiese Studies/Theological Studies 67(3), Art. \#997, 7 pages. http://dx.doi.org/10.4102/ hts.v67i3.997

(C) 2011. The Authors. Licensee: AOSIS OpenJournals. This work is licensed under the Creative Commons Attribution License.
The phenomena of friendship and giftship in antiquity have been the focus of much anthropological interest, yet those terms are still used much too broadly, wherein any one can be friends and anything exchanged is a gift. This article argued that proper friendship requires equality of exchange and status. When inequality of exchange is present, we will almost always also have inequality of status. These two things together naturally and necessarily result in the absence of frank speech. At this point, proper friendship (defined by frank speech) and the exchange of gifts (defined by equality of value) are impossible, and we have fictivefriendship, a term I have introduced in this article. Fictive-friendship refers to the practice, often but not exclusively amongst elites, of using friendship language to mask relationships of dependence (patronage and clientage). I closed my argument by looking at two examples of fictive-friendship in the Gospel of John.

\section{Introduction}

There exists in scholarship on antiquity - including New Testament scholarship - a good deal of imprecision in the use of the terminology of gifting. Typically, 'gift' is a catch-all term that covers things exchanged between family members, between an emperor and his governors and senators, his cities and their people, between a rich large-holder and his dependents, and between a master and a slave. Gifts, in other words, transcend social status and perhaps even erase it, a notion that surely serves as the foundation for the correlation of giftship with friendship.

It is arguable that this imprecision can be traced back to Marcel Mauss's highly influential work on the gift (Mauss 1990). Mauss developed what he, and others after him, believed to be a universal cross-cultural model of gift exchange from data drawn from the Melanesian and Andaman Islands, North-West Coast aboriginal and also, though to a lesser extent, from ancient Roman, Hindu and Germanic legal or literary texts. For Mauss, a gift was a something positive: it was traditional, old fashioned in the best sense, moral, healthy, mutually and universally beneficial, pleasant, personally binding and, above all, socially constructive. Mauss draws a very strong connection between giftship and friendship, which is also important for our purposes here. Throughout his work, Mauss stresses the close social relationships that derive from exchange, even in agonistic encounters such as the potlatch. For Mauss, to refuse a gift 'is tantamount to declaring war; it is to reject the bond of alliance and commonality' (Mauss 1990:17). In other words, it is a refusal of friendship, for gift exchange ignores status difference. Mauss's correlation of giftship and friendship is nowhere more strongly articulated than in Marshall Sahlins's comment summarising Mauss's work, that 'If friends make gifts, gifts make friends' (Sahlins 1972:186). For Mauss, as well as for the litany of scholars he influenced, gifts are both the raw materials that create civilised societies and the bond that keeps them from disintegrating.

Mauss's imprecise representation of giftship as a form of exchange and his correlation of it to friendship still persists. One example in which this is particularly evident is Paul Veyne's extremely influential and well-received work, Bread and circuses (1990):

Every class of the population benefitted from gifts. The poor received them as charity, or in the capacity of clients, or in that of free citizens. The slaves received them as a result of philanthropy or paternalism. The peasants, sharecroppers on the states of the rich, were forgiven their arrears of dues ... so long as they did not leave their master, this being, for landowners, a way of keeping tenants dependent upon them. Advocates, so long as their occupation was not recognized as a profession and they were forbidden to demand payment, received gifts from their clients as honorariums ... Corporations also received gifts. From the beginning of the Imperial period, making gifts to the Roman state was a privilege reserved of the Emperor alone. But the cities and municipalities of the Empire received gifts from the state nobility (the senatorial order), the regional nobility (the equestrian order), the notables who made up the municipal nobility (the order of decurians) and the rich freedmen ... The provinces of the Empire likewise received gifts, in a particular way.

(Veyne 1990:5-6) 
Clearly for Veyne, a 'gift' is anything that passes from one entity to another, regardless of other concerns, such as the relative status of the two parties, the relationship between them and the ability of one to repay the other. In very telling language, Veyne comments that the Hellenistic world looked 'like a society of "friends" and citizens' (Veyne 1990:8).

Veyne (1990) draws one interesting example of a gift from Polybius (Histories 4.65): Attalus of Pergamum fortified a fortress of the Aetolians and later the Aetolians supported Attalus in resisting Philip of Macedon. Veyne thus understands the purpose of Attalus's benefaction to have been the maintenance of useful political alliances. But he does not mention that this is also patron-client behaviour. The issue here is of primary cause versus secondary result: was the maintenance of useful political relations the cause or the result of the benefaction? In Veyne's very functionalist and irenic perspective (like that of Mauss), it can only be the latter. But to receive a benefaction is to be obligated to someone.

To anticipate evidence we shall encounter below, it was common knowledge that some people and states did not wish to be under an obligation, to be dependent or subordinate to others. That Veyne does not see this is surprising, when he notes that the Achaeans were unwilling to accept gifts from certain kings' (Veyne 1990:103). Of course they were; if accepting gifts put one in a position of being a client and having to follow certain customs of honour and obligation towards a patron nation or king, then it is fully understandable that some would be wary of entering into such a relationship.

At the greatest level of abstraction, there is no problem with using categories such as friendship and giftship expansively and letting them apply across as broad a range of exchanges and relationships as possible. The problem, as illustrated in Veyne's observations, is when we become interested in the actual social relationships and social dynamics between exchanging parties, not just in the general tenor of exchange, as was Mauss's interest. This is the point at which precision becomes desirable and because the Fourth Gospel is our exegetical focus, it is precision in an ancient Graeco-Roman setting that is needed. The driving questions in what follows are twofold: 'When is a gift not really a gift?' and 'Who can be friends?'

\section{Mapping exchange}

One way to limit confusion is to treat the term ' ift' $^{\prime}$ not as a general catch-all term, not as a category at the same level of abstraction as exchange, but rather to acknowledge that exchange is itself the broad category and that gifting is one specific type of exchange. This can be achieved by placing giftship accurately within the spectrum of exchange or reciprocity, which, of course, will be different for every culture and sometimes for subcultures too. It seems to me that this is rarely done in discussions of gifting.

Sahlins (as influenced by Mauss) was one of the first to aspire to map exchange more accurately by introducing three types of exchange: 'Generalised', 'Balanced' and 'Negative'. The first is situated within the larger kinship unit, is selfless, open ended and can withstand a long period before reciprocation happens. Sahlins (1972) offered as examples a mother's breastfeeding and food sharing amongst family members. The second type of exchange, 'Balanced reciprocity', moves us further from the kinship centre and thus is more prone to self-interest. As the name suggests, this type of exchange requires balance in what is exchanged and thus includes gift exchange, trades, buying and selling, and marriage contracts. Negative reciprocity moves us ever further from the kinship centre and is the least intimate or positive of the three types. Negative reciprocity threatens social stability because it tries to get something for nothing. Sahlins (1972) counted bartering, stealing and raiding in this group. Two features are useful in this typology: one is the recognition that exchanges that occur within kinship units are different from other types of exchange, for instance, that breastfeeding is not a gift one makes to one's child and, secondly, that gift exchange is a balanced form of exchange.

Nonetheless, the cross-cultural applicability of Sahlins's model is limited by two things. Firstly, the societies that were his focus were fairly egalitarian, in that they appear to have had little awareness of status difference. ${ }^{1}$ Secondly, Sahlins's model of exchange measures all forms of exchange based on their social distance from the kinship centre: the purest form of exchange is that between mother and child, because it is selfless, and exchange becomes increasingly selfish (and negative) from there. This might be fair for a society in which the principle social institution is kinship, but that does not describe Graeco-Roman society and thus some modifications have been made in order to fit the model better to GraecoRoman society. ${ }^{2}$

This can be accomplished by recognising that in the GraecoRoman world, kinship is not the central, binding institution that it is in the societies on which Mauss and Sahlins focused. In a society where kinship is central, everything is measured according to its proximity to the family, or social distance, as we saw with Sahlins's types of reciprocity. In the hyperstatus-conscious Graeco-Roman world, on the other hand, status distance replaces social distance. Yet, it is not at all the case that kinship is unimportant in Graeco-Roman cultures. This caveat cannot be overemphasised. It is not that kinship is absent from social concerns in the Graeco-Roman world, but rather that status is not derived singularly from it (as it is in the societies Mauss and Sahlins studied). In the Graeco-Roman world, status was derived from multivalent considerations that included (in no particular order) gender, education, ethnicity, wealth, power, and freedom (or its lack), in addition to kinship. ${ }^{3}$

1.As was the practice of the day, Mauss and Sahlins refer to the societies on which they focus as 'primitive' or archaic, defined by Sahlins as those 'lacking a political state' (Sahlins 1972:188). Aside from concerns over the problematic terminology, have found that describing the societies is more helpful than labelling them.

2.T.F. Carney also felt that Sahlins's simpler categories would have to be adapted to fit the more complex Graeco-Roman society (Carney 1973:64).

3. Having said this, it is possible that my observations on the demotion of kinship in the Graeco-Roman world might apply more to urban than rural settings, but even if kinship is more closely tied to status in rural settings, it still will not have been the sole factor. 


\section{The Graeco-Roman model of exchange}

For the Graeco-Roman world, a model of exchange based on status distance works better than one based on social distance. ${ }^{4}$ This model would look as follows.

\section{Familial exchange}

Broadly defined, this is the form of exchange that occurs within the family. It recognises, as Sahlins did, that familial exchange is different from extra-familial exchange and therefore needs to be set apart.

\section{Symmetrical exchange}

Symmetrical exchanges are those in which there is symmetry of status (of those doing the exchanging) and symmetry of value (of what is being exchanged). When the value of what is exchanged ceases to be symmetrical or balanced, the relationship breaks down. Hence, we find here, amongst other things, gift exchange, but also market exchange, a dynamic that requires some explanation.

It is not the case that gift and market exchange are indistinguishable, but simply that they are both to some extent symmetrical. In market exchange, it may not be that the relative status of buyer and seller are technically symmetrical, but rather that the relative status of the two does not (or should not) affect the transaction. When status intervenes in market exchange, then clearly the laws of market exchange have been usurped. There is definite symmetry in the market exchange itself, because the seller (with the help perhaps of market conditions) has decided on the value of a good and the buyer pays it. But consider the following hypothetical scenario: an elite leader enters a shop and the shop owner gives the elite everything for free. Clearly, the relationship has now become one of patronage and clientage. So the very point at which status intervenes in market exchange is the point at which market exchange ceases to be symmetrical. Thus, market exchange is symmetrical on value and somewhat symmetrical on status. The exchange of gifts conversely refers to exchanges between status equals with the ability to reciprocate with something equally valuable (value equality).

\section{Asymmetrical exchange}

Asymmetrical exchanges are those that occur between parties of unequal status involving exchanges of unequal value. Reciprocation is not made in kind, for if it were, it would become gift exchange (e.g. symmetrical). Counted here are exchanges of patronage and benefaction, where the parties involved are not status equals and where what they exchange is not of equal value (let alone equivalent kind). Asymmetrical exchanges, like symmetrical exchanges, can result in a powerful social dynamic, often resembling friendship, and equally often cast in the language of friendship, but as we shall see below, friendship is as much part of the domain of symmetrical exchange as is giftship.

4.What follows is my adaption of the Stegemanns's adaptation of Sahlins's model. See Stegemann and Stegemann (1995:34-37).

\section{Negative exchange}

Negative exchanges are those in which one party attempts to get more and give up less: haggling and cheating. I am less inclined than I once was to include stealing here. Stealing is redistributive but it is not really a form of exchange. In haggling or cheating, both parties come away with something, even if one comes away with less than would be ideal. ${ }^{5}$

The quest for precision requires us to acknowledge that, in a Graeco-Roman context at least, the exchange of gifts and the exchange of benefits (acts of patronage and benefaction) fall into two different types of exchange. The former is symmetrical, the latter is not, and the two are, it must be stressed, mutually exclusive. When exchanges become asymmetrical, they cease to be gifting and likely become patronage or something related. In fact, to turn the analogy around, when a benefaction is repaid in full, it is no longer a benefaction, for repayment transforms the exchange from asymmetrical to symmetrical. Of course, this is something that was sharply inadvisable according to Pliny (Ep. 10.51). A gift, therefore, within a Graeco-Roman context, is something exchanged between people with equal status and reciprocated with something of equal value. To illustrate: how does a freshly appointed governor repay the emperor for his patronage? Even a governor, elite though he is, lacks the status, power and resources to give the emperor anything he does not already have or have access to. How does a poet repay the one who supports his poetic endeavours financially and secures him an audience? If the poet could do the same for his patron (symmetrical exchange) he would not have needed a patron in the first place.

To say that gift exchange and patronage - symmetrical and asymmetrical exchanges - are mutually exclusive is not to deny that they are easily confused, which explains past imprecision. In both cases, things are exchanged; gratitude, reciprocity, respect, honour, et cetera, are all expected responses; a long standing relationship results, as does goodwill. It is even possible for frank speech, Plutarch's truest test of friendship, to appear in asymmetrical relationships. But gifting and patronage are not the same thing, nor are friendship and patronage. The reason why gifting and patronage are so easily confused in the Greek and Roman periods is because of their culturally peculiar practice of using friendship language to make asymmetrical relationships and exchanges appear symmetrical.

Receiving an act of patronage required one to broadcast one's dependence upon a superior and, by extension, to broadcast one's lower relative status. Because of this, both Greeks and Romans appropriated the language of friendship - фí̀os in Greek, amicitia in Latin - in order to mask relationships of dependence or inequality. One never finds patrons referring to fellow-elite clients as clients; they are always referred to as 'friends'. There is a difference of opinion on how to interpret this. David Konstan $(1995,1997)$ has argued that the language of friendship is used because friendship describes

5.See Crook (2006:91). 
the relationships in question. Konstan points out, correctly of course, that these people knew the difference between friendship and clientage, so we should trust them to so distinguish. Whilst I agree with Konstan that ancient people knew the difference between clients and friends, I find more compelling the direction of those who argue that the friendship language is a 'coyness' and 'dressing up' of status and exchange inequalities. ${ }^{6}$ Attention to status and exchange equality - in the form of culturally appropriate models of giftship and friendship - can contribute to this interesting debate.

\section{Exchange and social status}

All gifts obligate, but a gift from a social superior obligates in a way that inscribes the inequality and inferiority of the person with the lower status, whereas a gift exchanged between status equals - friends - obligates positively and inscribes their equality. The best way to illustrate the difference is to attend to the stigma many knew of relationships of dependence. Cicero claims that wealthy people were loath to be put under an obligation of any kind: 'it is bitter as death to them to have accepted a patron or to be called clients' (De. Off. 2.69). The people Cicero imagines in this position would have been elite. The plebs were surely accustomed to being called much worse and were, in any case, too reliant to be so concerned with perceptions.

Seneca expresses something similar: 'There are some who are not willing to receive a benefit unless it is privately bestowed' (De ben. 2.23.1; LCL). Others accept, but try to give their thanks privately, quietly, and away from the crowds. Seneca charges these people with repudiation and ingratitude (2.23.2), an exceedingly serious social ill according to Seneca: 'Homicides, tyrants, thieves, adulterers, robbers, sacrilegious men, and traitors there always will be; but worse than all these is the crime of ingratitude' (De ben. 1.10.4). In trying to avoid the odious reputation of being a client (clientium), they end up with a far worse reputation: that they are ingrates (2.23.3). On the stigma of receiving of benefits, Seneca (De brevitate vitae) laments - whilst discussing another topic the condition of those who are engrossed in other people's business, whose sleep and wake, the pace of their walk, and who they like and dislike are dictated by another (De brev. vit. 19.3). Clients, in other words, are no better off than slaves.

Juvenal lampoons the treatment clients receive from their patrons. Wealthy patrons stack their parties with clients, both in order to placate them but also in order to make their parties seem well attended. But patrons then treat some clients with contempt. He relates open insults, indignities, and being forced to eat scraps fit only for dogs (Satire 5.811) and drink wine that not even fresh-clipped wool would want to suck up (Satire 5.24-25). Even the water the patron

6.See Smith (2003:145). See also Saller (1982:15) and Saller (1989). I think the difference between the two positions is easily explained: Konstan is interested in the experience of friendship - and he is quite right that feelings of friendship could the experience of friendship - and he is quite right that feelings of friendship could be found in unequal relationships - whereas others (myself included) are interested not in the experience of friendship but in the institution, which has requirements,

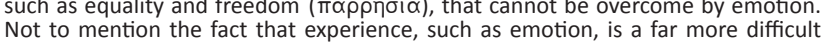
Not to mention the fact that experience, such as emotion, is a far more diffic
measure of something than something like status and exchange asymmetry. drinks is better (Satire 5.51-52). Juvenal, it must be admitted, is writing satire, not social history; nonetheless, satire and exaggeration are not funny if they are not grounded to some degree in reality. ${ }^{7}$

Paul Millett (1989) suggests that the reason one might wish not to become dependent on a social superior has to do with a concern over slavishness, a concern that goes back to Aristotle. The person of lower status in an unequal relationship 'is forced to compromise his $\varepsilon \lambda \varepsilon v \theta \varepsilon \rho$ ía by adapting his behaviour to gratify his potential benefactor, on whose favours he is dependent' (Millett 1989:33). The stigma associated with relationships of dependence, and the reception of benefactions as opposed to the reception of gifts, is evident in another Graeco-Roman practice: the use of friendship language to mask relationships of dependence.

All of this illustrates the status awareness of ancient people, particularly elites. It also illustrates the stigma associated with relationships of dependence that naturally lead to the usurpation of the language of friendship. Let us look at two examples of this, one Greek and the other Roman, and from different periods. I cannot be exhaustive here, of course, so my hope in choosing these two examples is that they will illustrate that we are dealing here with wide-spread cultural practices, not the idiosyncrasies of specific localities.

\section{Xenophon}

Writing in Athens in the 4th century BCE, Xenophon relates a conversation (Memorabilia 2.9) in which Socrates advises Criton on how to get out from under threats of blackmail: blackmail them back. Socrates asks, 'Why not keep a man' around to act as a dog guarding the sheep? When Criton worries that even this man would turn on him, Socrates assures him there are many men in the city would be honoured to be a фí̀os to Criton (2.9.3). Given the context, clearly Xenophon's Socrates is not imagining someone of equal social station to Criton, so he cannot be suggesting the two will actually be close friends. He is suggesting using one of Criton's clients to do some dirty work. Proving this point, Criton settles on Archedemus, an eloquent but poor man. Archedemus is so good at persuading people to drop their actions against Criton that soon Criton's $\phi^{\prime}(\lambda \circ \mathrm{o}$, in this case social equals, want to employ Archedemus too (2.9.7).

Archedemus is not Criton's social equal; he is a client. In return for Archedemus's work, Criton gives him provisions from his crops, wine, wool and invites him to dinners. There

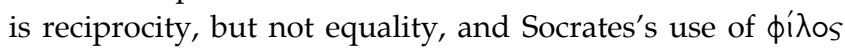
earlier does not imply real friendship. Nor does Xenophon think so: he refers to Archedemus as Criton's dog from which the other shepherds (Criton's friends) want to benefit (2.9.7). It is the stereotypical patron-client relationship, so of course Archedemus is eventually mocked by his peers; they call him кó $\propto \xi \xi$ (2.9.8), because he does not have the freedom to speak his mind. Archedemus responds lamely with the claim that

7.This makes Duncan Cloud's (1989) claim that Juvenal's satirical presentation cannot be thought realistic in any way inexplicable. 
it is better to have honest men like Criton and his friends as $\phi i \lambda$ o I than to be dishonest yourself. Xenophon closes with the observation that Archedemus came to be counted amongst Criton's $\phi$ í $\lambda$ o , but clearly the friendship is fictive, even allowing for Criton's deep appreciation of Archedemus's work.

\section{Horace}

A second example comes from the Augustan poet Horace, who warns Lollius away from seeking out a rich patron. Proper friendship requires the ability to speak freely ( $\left.\pi \propto \rho \rho \sigma^{\prime} \alpha\right)$, which derives exclusively from social equality. Horace's advice to Lollius cannot be idiosyncratic: there is no freedom in unequal friendships. If one's 'friend' wishes to go hunting, one does not get to spend the afternoon writing poetry (1.18.39-40); great care is needed in what one says, to whom and about whom it is said, because incriminating words always find a way of migrating back to one's patron (1.18.67-69); and extreme caution needs to be exercised when one introduces someone new to a patron (1.18.76-85). Horace even warns Lollius away from seeking a relationship with a great friend altogether: 'Those who have never tried think it pleasant to court a friend in power; one who has tried dreads it' (1.18.86-87; LCL). This is not freedom and it is therefore not true friendship. Where status equality is absent, there cannot be true friendship for true friendship does not require

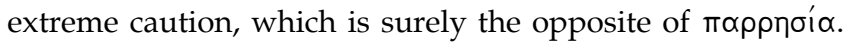
The 'friendship' is a fiction and Horace knows it full well, probably from personal experience.

Never once in this letter does Horace use the words patronus or cliens; he uses amicus exclusively and both to describe Lollius $(1.18 .4,101)$ and the would-be patron $(1.18 .24,44,73$, 86). It comes as some surprise then when the Loeb translator (Fairclough 1991) uses 'patron' to translate a masculine demonstrative adjective (illius; at 1.18.37). Of course, the person referred to is a patron, but Horace would never call him that and the translation misses Horace's own cultural sensitivity.

These two examples are illustrative. On the one hand, both show that the people in question distinguished quite attentively between kinds of friends and social status, but, on the other hand, they also show that vocabulary tells us nothing about these distinctions. The language of friendship abounds, but only attention to the combination of status difference and $\pi \alpha \rho p \eta \sigma i \alpha$ tells us that Archedemus and Criton share a fictive-friendship, whilst Criton and the others who wished also to benefit from Archedemus's skill were proper friends. Likewise, it is inconceivable that either Horace or Lollius were under any illusion that 'friendship' was really what Lollius was in search of.

Anthropological work confirms that there is a spectrum from emotional friendship to instrumental friendship and onwards to patronage, depending upon affection and on the degree of imbalance: what may start out as a symmetrical reciprocal relationship between equal parties may ... develop into a relation in which one of the parties ... develops a position of strength, and the other a position of weakness.

(Wolf 1966:13)

Yet, friendship is fluid; it can cease to be become friendship when imbalance becomes conspicuous:

When instrumental friendship reaches a maximum point of imbalance so that one partner is clearly superior to the other in his capacity to grant goods and services, we approach the critical point where friendships give way to the patron-client tie.

(Wolf 1966:16)

\section{Friendship and fictive-friendship: A model}

A number of features of the ancient world need to be brought together in order to understand this model. These features are drawn from ancient sources and supplemented by anthropological ways of thinking about exchange. Firstly, it is worthwhile to note that ancient Mediterranean societies were profoundly aware of status, as can be seen from the two examples above, amongst others. Secondly, in a vertically structured society, everyone with honour was acutely aware of their position in the hierarchy: there were people with less honour, but there were also always people with more honour. If ancient sources are any indication, there seems to have been an understanding amongst elites not to draw undue attention to the relative status differences amongst them. Thirdly, the language of friendship was appropriated to mask unequal but elite relationships and thus to diminish the shame associated with relationships of dependence. Finally, exchanges of patronage and giftship are mutually exclusive forms of exchange, representing asymmetrical and symmetrical status exchanges respectively. Treating the terminology as interchangeable is therefore obfuscating, not enlightening.

The model illustrates what the ancient sources reveal: that when the status of the parties (horizontal axis) is symmetrical and when the value of what is exchanged (the horizontal axis) is also symmetrical, we have friendship (and, incidentally, the exchange of gifts). Conversely, when the status of the parties are asymmetrical and when the value of what is exchanged is also asymmetrical, we have clientage (and, incidentally, patronage or benefaction). Fictive-friendship arises somewhere between those two poles. The benefit of the range implied in the model is that there is no hard line between friendship, fictive-friendship and clientage. Much depends on the specific circumstances. Nonetheless, fictivefriendship refers to those relationships of dependence in which the language of friendship is used to mask a relationship of dependence and to diminish the attendant stigma (Figure 1).

8.Wolf's (1966) observation is reflected also in Latin American ethnographic work Lola Romanucci-Ross (1973) writes about a Mexican village in which society is vertically and hierarchically structured, much like the ancient Mediterranean vertically and hierarchically structured, much like the ancient Mediterranean
world. She writes that 'Friendship in the village is a horizontal relation - i.e., it world. She writes that 'Friendship in the village is a horizontal relation - i.e., it
exists among people are, roughly, peers on any given level. It does not (and, as far as we know, cannot) exist among people who are vertically much separated far as we know, cannot) exist among people who are vertically much separated
in status, because this would automatically produce a patronage relation' in status, because this would
(Romanucci-Ross 1973:74-75). 


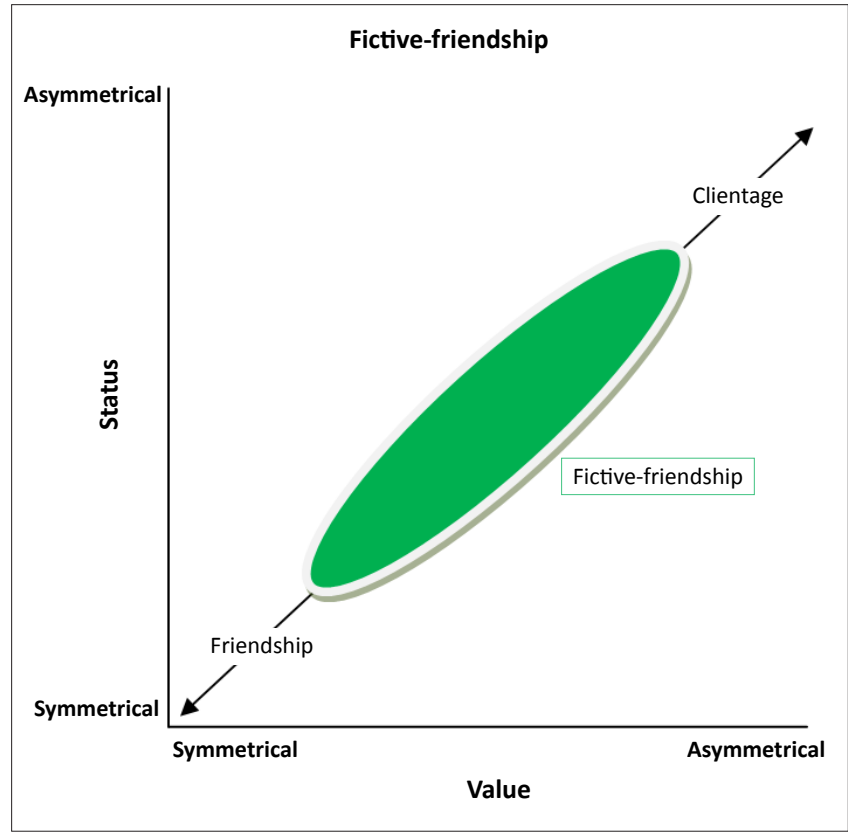

FIGURE 1: The relationship between friendship, fictive-friendship and clientage in correlation to the value of the exchange and the status of the parties involved in it.

Before we examine how the model illuminates selected passages from the Fourth Gospel, a few caveats concerning the term 'fictive-friendship' are in order. Most importantly, the term, a neologism as far as I can tell, is not meant pejoratively. It is meant in the same neutral manner as the term 'fictive-kinship'. The language of kinship was used in many circles where the kinship was not technical. Also, the term fictive-friendship is not meant to deny the possibility that there may, in some cases, have been real feelings of affection between people of unequal status in relationships of dependence. The term focuses on status equality and not on the emotion or affection of the individuals involved. Besides, ancient writers are consistent on this point: if both parties do not have total freedom to speak their mind, which typically requires status equality, then the relationship we are seeing is not really friendship. Ultimately, then, it is not a question of whether two people had friendly feelings for each other (say,

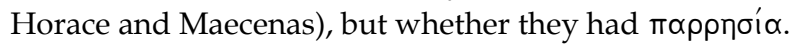

\section{Fictive-friendship in John 15:12-17 and 19:10-13}

There are two places in the Fourth Gospel where the word p'ìos is used in a way that illustrates the challenge of understanding ancient uses of friendship language in light of status difference and obligation: John 15:12-17 and 19:10-13.

In John 15:14-17, Jesus has some surprising things to say about friendship, especially from an ancient Mediterranean perspective:

${ }^{14}$ You are my friends if you do what I command you. ${ }^{15} \mathrm{No}$ longer do I call you servants, for the servant does not know what his master is doing; but I have called you friends, for all that I have heard from my Father I have made known to you. ${ }^{16}$ You did not choose me, but I chose you and appointed you that you should go and bear fruit and that your fruit should abide; so that whatever you ask the Father in my name, he may give it to you. ${ }^{17}$ This I command you, to love one another.

(Jn 15:14-17)

There are so many reasons why it is hard to accept that friendship is really what Jesus - according to the author of the Fourth Gospel - has in mind. The first is not reflected in this passage but in the Fourth Gospel as a whole. The Fourth Gospel goes further than any other New Testament work in its high Christology, in its association of Jesus with God. Jesus therefore cannot have the same status as his disciples, or anyone for that matter, because he is, in the narrative framework of this gospel, essentially equal with God. In a Graeco-Roman context, then, Jesus is not their friend.

What he is to the disciples, however, is reflected in this passage: he is their broker. ${ }^{9}$ God is the patron and Jesus mediates (Jn 15:16). In the real world, the broker is not the patron, but he does have a higher status than the client and, by acting as a mediator between the patron and client, provides the client with a benefaction in and of itself (Batten 2010; Neyrey 2005, 2007). The broker is a second patron to a client and thus this person can expect to be treated somewhat like a patron: he can expect gratitude, honour and, to some extent, loyalty. Thus in a second way, as broker, Jesus in this passage is does not have status equality with the disciples or any of his followers.

That a lack of status equality between Jesus and his disciples is assumed in this passage is apparent in the two times that Jesus commands ( $\left.\varepsilon^{\prime} \nu \tau^{\prime} \hat{\prime} \lambda \lambda \omega\right)$ the disciples. In no ancient definition of friendship does one find that a friend is one who does what he is commanded. Clearly, a lack of status equality must be present in order for one 'friend' to command another, which is certainly what we find in relationships of dependence and obligation, which also use the language of friendship, but do not describe actual friendship.

That Jesus, in view of John's high Christology, has a substantially higher status than the disciples, that he is in this passage - and, according to Neyrey (2007), throughout the Fourth Gospel - cast in the role of broker, and that he commands his disciples suggests that the category of fictivefriendship applies here. Jesus claims the disciples as friends, but clearly he is their superior and they are obligated to him. This would make the relationship one of fictive-friendship, not actual friendship.

The second interesting instance of friendship language comes from the trial narrative, which depicts Pilate as increasingly convinced that Jesus is no more than a madman and certainly not the threat 'the Jews' make him out to be. When Pilate

9. One sees here a tension in the Fourth Gospel that results from the fact that early Christians are in the process of working towards a Trinitarian theology, but are not there yet: on the one hand, the Christology of the Fourth Gospel is far advanced of synoptic Christology, and yil a move that Malina (1996:151) correctly points out does not occur in Christian theology until the 4th century CE - the implication is that Jesus and God are not quite yet interchangeable. 
announces his intent to release Jesus, 'the Jews' threaten him: 'If you release this man, you are no friend ( $\phi$ ínos) of Caesar. Every man who makes himself a king opposes Caesar' (Jn 19:12). Both those making the threat and Pilate know full well that Pilate and Tiberius are not friends; they are not social equals. Tiberius is the Roman Emperor and lacks for nothing; if that were not enough to indicate that he and Pilate are not social equals, the fact that he appointed Pilate prefect over Judea makes it certain that he is Pilate's patron, not his friend. Yet, Pilate is an elite and 'the Jews' must avoid antagonising him, because (according to the narrative of the Fourth Gospel) they need him to do what they legally cannot, namely dispatch Jesus. For 'the Jews' to have referred to Pilate as what he is - Tiberius's client - would have shamed him. The language of friendship is used in order to hide the stigma of Pilate being an elite dependent. It is all illusion of course - the friendship between Pilate and Tiberius is fictive - but as with all social convention, it is no less effective for that.

\section{Conclusion}

The language of friendship was multivalent in GraecoRoman antiquity. It is not that people in these cultures did not distinguish between friendship and other relationships (e.g. slavery, manumission, marriage and patronage). They most certain did and both cultures were highly aware of status differences. And yet, the language of friendship was used in many instances that did not pertain to actual friendship, at least in the purest sense. Friendship language was often used to place a veneer over relationships of dependence precisely because of the status consciousness of these cultures. To be a dependent was common, yet shameful. It was rare therefore to refer to client as clients (it was more common, because of the honour inherent in the title, to refer to patrons as patrons). Instead the language of friendship was used. I have argued in this paper for a new category that we might call fictivefriendship: it is found most commonly (in a Roman setting) between fellow elites, but can be found in Greek settings that do not involve fellow elites, and in the Fourth Gospel. FictiveFriendship is to be understood like fictive-kinship: not to cast aspersions on a relationship (did two people actually like each other), but to note the redeployment of language from one institution (a friendship-like kinship) for use in a much more diffuse way and with a social function.

\section{Acknowledgements}

I gratefully acknowledge my South African colleagues from the University of Pretoria and Unisa for their critical feedback and questions during the sessions of the International Meeting of the Context Group, and to the University of Pretoria for inviting me to attend. Gratitude is especially due to the tireless efforts of Prof. Dr Ernest van Eck for making it all happen.

\section{References}

Batten, A.J., 2010, 'Brokerage: Jesus as social entrepeneur', in D. Neufeld \& R.E. DeMaris (eds.), Understanding the social world and the New Testament, pp. 167-177, Routledge, New York, NY.

Carney, T.F., 1973, The economies of antiquity, Coronado Press, Lawrence, KS.

Cloud, D., 1989, 'The patron-client relationship: Emblem and reality in Juvenal's first book', in A. Wallace-Hadrill (ed.), Patronage in ancient society, pp. 205-218, Routledge, New York, NY.

Crook, Z., 2006, 'Reciprocity: Covenantal exchange as a test case', in P. Esler (ed.), Ancient Israel: The Old Testament in its social context, pp. 78-91, Fortress Press, Minneapolis, MN.

Fairclough, H.R., 1991, Satires, Epistles, Ars Poetica, Loeb Classical Library, Harvard University Press, Cambridge, MA.

Konstan, D., 1995, 'Patrons and friends', Classical Philology 90(4), 328-342. http:// dx.doi.org/10.1086/367478

Konstan, D., 1997, Friendship in the classical world, Cambridge University Press, Cambridge. http://dx.doi.org/10.1017/СBO9780511612152

Malina, B.J., 1996, The social world of Jesus and the Gospels, Routledge, London.

Malina, B.J. \& Rohrbaugh, R.L., 1992, Social-Science commentary on the Synoptic Gospels, Fortress Press, Minneapolis, MN.

Mauss, M., 1990, The gift: The form and reason for exchange in archaic societies, transl. W.D. Halls, Routledge, London.

Millett, P., 1989, 'Patronage and its avoidance in classical Athens', in A. Wallace-Hadril (ed.), Patronage in ancient society, pp. 15-47, Routledge, New York, NY.

Neyrey, J.H., 2005, 'God, benefactor and patron: The major cultural model for interpreting the deity in Greco-Roman antiquity', Journal for the Study of the New Testament 27(4), 465-492. http://dx.doi.org/10.1177/0142064X05055749

Neyrey, J.H., 2007, “'I am the door" (John 10:7, 9): Jesus the broker in the Fourth Gospel', Catholic Biblical Quarterly 69(2), 271-291.

Neyrey, J.H. \& Rohrbaugh, R.L., 2001, “'He must increase, I must decrease” (John 3:30): A cultural and social interpretation', Catholic Biblical Quarterly 63(3), 464-483.

Romanucci-Ross, L., 1973, Conflict, violence, and morality in a Mexican village, National Press Books, Palo Alto, CA.

Sahlins, M., 1972, Stone age economics, Aldine de Gruyter, New York, NY.

Saller, R., 1982, Personal patronage under the early empire, Cambridge University Press, New York, NY. http://dx.doi.org/10.1017/CBO9780511583612

Saller, R., 1989, 'Patronage and friendship in early Imperial Rome: Drawing the distinction', in A. Wallace-Hadrill (ed.), Patronage in ancient society, pp. 49-62, Routledge, New York, NY.

Smith, R.B.E, 2003, "Restored utility, eternal city": Patronal imagery at Rome in the Fourth Century AD', in K. Lomas \& T. Cornell (eds.), 'Bread and circuses' Euergetism and municipal patronage in Roman Italy, pp. 142-166, Routledge, New York, NY.

Stegemann, E. \& Stegemann, W., 1995, The Jesus movement: A social history of its First Century, Fortress Press, Minneapolis, MN.

Veyne, P., 1990, Bread and circuses: Historical sociology and political pluralism, transl. B. Pearce, Allen Lane, London.

Wolf, E.R., 1966, 'Kinship, friendship, and patron-client relations', in M. Banton (ed.), The social anthropology of complex societies, pp. 1-22, Frederick Praeger, New York, NY. 